\title{
Arctic ozone loss in early spring and its impact on the stratosphere- troposphere coupling
}

\author{
ShuYang $\mathrm{Yu}^{1,2}$, Jian Rao ${ }^{1,2}$, and Dong Guo 1,2,3* \\ ${ }^{1}$ Key Laboratory of Meteorological Disaster, Ministry of Education (KLME) / Joint International Research Laboratory of Climate and Environment Change \\ (ILCEC) / Collaborative Innovation Center on Forecast and Evaluation of Meteorological Disasters (CIC-FEMD), Nanjing University of Information Science and \\ Technology, Nanjing 210044, China; \\ ${ }^{2}$ School of Atmospheric Science, Nanjing University of Information Science and Technology, Nanjing 210044, China; \\ ${ }^{3}$ Reading Academy, Nanjing University of Information Science and Technology, Nanjing 210044, China

\section{Key Points:} \\ - Arctic ozone loss events occur once in early spring every 14-15 years on average. \\ - Early reversal of stratospheric NAM (Northern Annular Mode) when early spring Arctic ozone loss events occur. \\ - Ozone loss in early spring favors a warming of the near surface over the Arctic.
}

Citation: Yu, S. Y., Rao, J., and Guo, D. (2022). Arctic ozone loss in early spring and its impact on the stratosphere-troposphere coupling. Earth Planet. Phys., 6(2), 177-190. http://doi.org/10.26464/epp2022015

\begin{abstract}
The tropospheric impact of Arctic ozone loss events is still debatable. In this study we investigate that question, using the ERA5 reanalysis and long-term integration by a climate-chemistry coupled model (CESM2-WACCM). We begin with the frequency of Arctic ozone loss events. On average, such events occur once in early spring every 14-15 years in ERA5 data and in the model, both of which estimate that roughly $40 \%$ of the strong polar vortex events in March are coupled with Arctic ozone loss, the remaining $60 \%$ being uncoupled. The composite difference between the two samples might be attributed to the pure impact of the Arctic ozone loss - that is, to ozone loss alone, without the concurrent impact of strong polar vortices. Arctic ozone loss is accompanied by an increase in total ozone in midlatitudes, with the maximum centered in the Central North Pacific. Contrasting Arctic ozone loss events with pure strong polar vortex events that are uncoupled with ozone loss, observations confirm that the stratospheric Northern Annular Mode reverses earlier for the former. For pure strong vortex events in early spring (without Arctic ozone loss), the cold anomalies can extend from the stratosphere to the middle troposphere; when such events are strong, the near surface warm anomalies are biased toward the continents. In contrast, during the other $40 \%$ of strong early-spring polar vortex events, those coupled with ozone loss, a concurrent and delayed warming of the near surface over the Arctic and its neighboring areas is observed, due to vertical redistribution of solar radiation by the change in the ozone.
\end{abstract}

Keywords: Arctic ozone loss; strong polar vortex; CESM2-WACCM; historical run

\section{Introduction}

Ozone is an extremely important trace gas in the Earth's atmosphere (Turnock et al., 2019), and its variations have significant impacts on ecosystems, climate, and the environment (Rex et al., 2004; Ashmore, 2005; Fowler et al., 2009). Most atmospheric ozone is concentrated in "the ozone layer" inside the stratosphere, which protects life on Earth by absorbing most of the sun's damaging ultraviolet radiation (Rowland, 2006; Douglass et al., 2014). Stratospheric ozone converts the absorbed ultraviolet radiation to heat, warming the atmosphere, thus accounting for the observation that temperature increases with height in the stratosphere; ozone thus plays a significant role in maintaining the static stabil-

Correspondence to: D. Guo, Dongguo@nuist.edu.cn

Received 06 AUG 2021; Accepted 10 DEC 2021.

Accepted article online 28 JAN 2022.

C 2022 by Earth and Planetary Physics. ity of the stratosphere (Cheung et al., 2014; Bai XY et al., 2021).

Since the 1980s, Antarctic total column ozone has experienced a rapid decrease in the austral spring, a phenomenon that has come to be known as the "Antarctic ozone hole" (Stolarski et al., 1986; Douglass et al., 2014). The Antarctic ozone hole has appeared annually every austral spring since then (Farman et al., 1985; Solomon et al., 1986; Chipperfield et al., 2015). Antarctic stratospheric ozone content is not expected to recover fully to preOzone Hole levels until the second half of the 21 st century (World Meteorological Organization, 2002). It is well documented that the Antarctic ozone hole has an impact on the Southern Annular Mode (SAM) and stratosphere-troposphere coupling, which in turn affects surface climate change in the Southern Hemisphere (Thompson and Solomon, 2002; Thompson et al., 2011; Ivy et al., 2017; Smith and Polvani, 2017). The effect of ozone depletion on the stratospheric SAM is explained by the increased frequency of extreme anomalies due to ozone depletion, reduced absorption 
of incident shortwave radiation by stratospheric polar ozone, and increased meridional temperature gradients (Dennison et al., 2015). The impact of the Antarctic ozone hole on the SAM has led to a series of significant Southern Hemisphere surface climate changes in such regions as Antarctica, the Southern Oceans, New Zealand, Patagonia, Southern Australia (Solomon, 1999; Renwick, 2002; Marshall et al., 2006; Hendon et al., 2007), and even the far Southern Tropics (Thompson et al., 2011).

Recent studies have reported that ozone loss events are not exclusive to the Antarctic, but occur irregularly also in the Arctic (Newman et al., 1997; Bernhard et al., 2013; Manney et al., 2020). Three such extreme low-ozone events in early spring (March) have been observed since 1979: in 1997, 2011, and 2020 (Newman et al., 1997; Arnone et al., 2012; Zhang Y et al., 2013; Manney et al., 2020; Rao J and Garfinkel, 2020, 2021). Compared with the annual austral spring ozone loss over Antarctic, these three sporadic ozone loss events in the Arctic have been relatively weak (Rex et al., 2006; Arnone et al., 2012). Significant ozone loss over the Arctic has occurred only when the stratospheric polar vortex persisted into spring and the lower stratospheric temperatures were unusually low (Arnone et al., 2012). Each of these three extreme ozone loss events was coupled to the strong and cold stratospheric polar vortex, and the Northern Annular Mode (NAM) also developed toward extreme positive polarity (Rao J and Garfinkel, 2020).

However, none of the observational evidence directly indicates a clear relationship between Arctic ozone loss and surface climate (Karpechko et al., 2014; Harari et al., 2019; Rao J and Garfinkel, 2020). Harari et al. (2019) reported that the superficial tropospheric response to Arctic ozone loss may related dynamically to the strong polar vortex. Rao J and Garfinkel (2020) found that better prediction of the Arctic ozone loss is not directly related to improved predictability of surface conditions. The link between the 2011 lower Arctic stratospheric ozone anomaly and tropospheric climate reported in a model study by Karpechko et al. (2014) was stable only when the ozone anomaly coincided with the sea surface temperature anomaly.

This paper will explore the impact on the stratosphere-troposphere coupling and surface climate when the strong polar vortex is coupled to Arctic ozone loss. By comparing the impact of strong polar vortex events, coupled and uncoupled to the Arctic ozone loss, we seek to isolate the direct impact of the Arctic ozone loss from the dynamical impact of the strong polar vortex state.

Organization of the paper is as follows. Following the introduction, Section 2 describes data and methods. The frequency of the Arctic ozone loss events in the limited reanalysis and long-term simulation by a chemistry-climate coupled model is presented in Section 3. Section 4 discusses the possible impact on the surface climate of strong stratospheric polar vortex events coupled to the Arctic ozone loss. In order to exclude the effect of the strong polar vortex state from that of the ozone loss, Section 5 compares the impacts of strong polar vortex events with and without their being coupled to an Arctic ozone loss. The difference between the coupled and uncoupled cases is hypothesized to be the direct impact of the Arctic ozone loss, on the assumption that the impacts of the strong polar vortex and the Arctic ozone loss can be super- imposed linearly. Finally, conclusions and discussion are provided in Section 6.

\section{Data and Methods}

\subsection{ERA5 Reanalysis Dataset}

ERA5 is the fifth-generation reanalysis product released by the European Centre for Medium-Range Weather Forecasts (ECMWF). Monthly circulation and total ozone column $\left(\mathrm{TO}_{3}\right)$ data at $0.5^{\circ} \times$ $0.5^{\circ}$ horizontal resolution is available from the Copernicus Climate Change Service Climate Data Store after registration (https:// cds.climate.copernicus.eu). ERA5 assimilates 19 different ozone observation sources at different times since 1979 (Hersbach et al., 2020), so it is reasonable to use $\mathrm{TO}_{3}$ from the modern reanalysis as the reference state.

\subsection{Model and Simulations}

Historical simulations provided by a climate-chemistry-coupled model, CESM2-WACCM, are employed in the study. CESM2 is abbreviated from Community Earth System Model version 2, developed by the National Center for Atmospheric Research (NCAR). CESM2 is a state-of-the-art fully coupled model that includes interacting ocean (POP), land (CLM), sea ice (CICE), and atmospheric components with interacting chemistry (Thiéblemont et al., 2016). As a global three dimensional "troposphere-stratosphere-mesosphere-thermal bottom" atmospheric model developed by NCAR in recent years, the Whole Atmosphere Community Climate Model version 6 (WACCM6) is the chosen atmospheric component for CESM2-WACCM. Different versions of WACCM were used to study the impacts of the stratospheric ozone hole on the following: climate (Eyring et al., 2007, 2010), geoengineering (Tilmes et al., 2018), ENSO pathways in the stratosphere (Zubiaurre and Calvo, 2012; Rao J and Ren RC, 2016), and sudden stratospheric warmings (Thiéblemont et al., 2016; Cao C et al., 2019; Liu SM et al., 2019).

CESM2-WACCM participated in Phase 6 of the Coupled Model Intercomparison Project (CMIP6), whose goals were to better understand past, present, and future climate changes that are caused by natural, unforced variability or response to changes in radiative forcing in a multi-modal context (Eyring et al., 2016). Three CMIP6 experiments by CESM2-WACCM are used in this study, forced by observed emissions from 1850 to 2014. These three historical runs start from different initial conditions but with the same dynamic and physical frame in the model. The monthly outputs for ozone content, air temperature, geopotential height, and surface temperature are collected from the CMIP6 database (https://esgfnode.Innl.gov/search/cmip6/). Historical runs by CESM2-WACCM have a horizontal resolution of $0.9^{\circ} \times 1.25^{\circ}$ (latitude $\times$ longitude), spanning the period from January 1850 to December 2014 .

The total column ozone $\left(\mathrm{TO}_{3}\right)$ is not a standard output for CMIP6, but can be estimated by vertically integrating the ozone concentration from surface to the model's top (Tang Z et al., 2019; Rao J and Garfinkel, 2020, 2021). First, the ozone metric in units of molar ratio (i.e., the volume ratio as per Avogadro's law) from historical simulations is converted to a mass mixing ratio $\left(\mathrm{RO}_{3}\right)$ by multiplying the molecular weight ratio between ozone and the well- 
mixed atmosphere (i.e., 48/29). Second, a vertical integration of the ozone mass mixing ratio by pressure is performed to obtain the total column ozone $\left(\mathrm{TO}_{3}\right), \mathrm{TO}_{3}=\frac{1}{g} \int_{0}^{P_{\mathrm{s}}} \mathrm{RO}_{3} \mathrm{~d} p$, where $P_{\mathrm{s}}$ is the surface pressure and $g$ is the gravitational acceleration constant ( $g$ $=9.8 \mathrm{~m} / \mathrm{s}^{2}$ ). Finally, the units of $\mathrm{TO}_{3}$ are converted from $\mathrm{kg} / \mathrm{m}^{2}$ to the Dobson Unit (DU) with a rough estimation of $1 \mathrm{DU}=2.1415 \times$ $10^{-5} \mathrm{~kg} / \mathrm{m}^{2}$ (Zhang ZM et al., 2019).

\subsection{Methods}

Time series of the Arctic total column ozone, area-averaged over $65-90^{\circ} \mathrm{N}$ in March, is calculated as the "Arctic ozone index" to identify major ozone loss events in early spring. Such anomalous Arctic ozone loss events are identified in the three historical runs when the ozone index drops below the run's average value by at least 1.5 times its standard deviation. This study uses a lead/lag composite analysis of the selected Arctic ozone loss events, diagnosing the circulation and ozone in the leading and following months for each major March Arctic loss event.

To separate the direct impact of the Arctic ozone loss from the dynamic influence of the strong polar vortex, all strong polar vortex
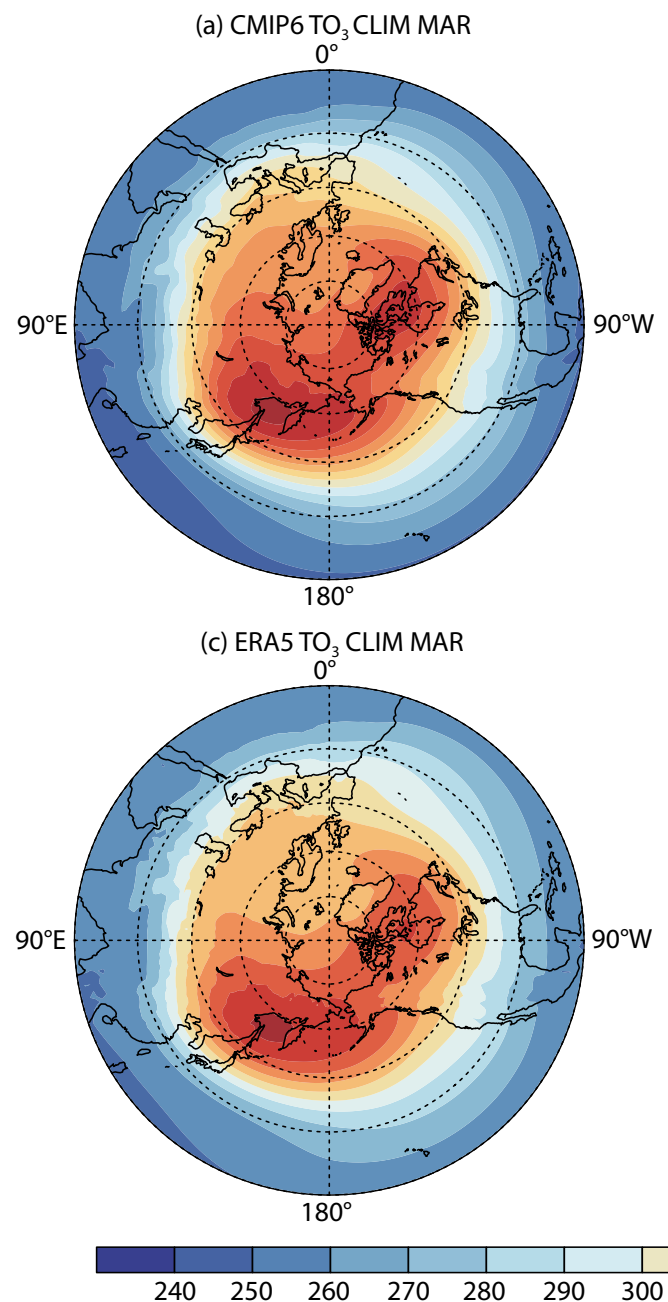

events in early spring are selected if the polar cap $\left(65-90^{\circ} \mathrm{N}\right)$ height anomaly at $10 \mathrm{hPa}$ in March is larger than its standard deviation. (Choosing the polar cap height to be 50 or $70 \mathrm{hPa}$ instead of $10 \mathrm{hPa}$ does not significantly change the selection of strong polar vortex events.) Arctic ozone loss events are a subset of the strong polar vortex events, and the composite results for the Arctic ozone loss events are actually a combined response. The difference between Arctic ozone loss events and strong polar vortex events uncoupled to Arctic ozone loss might reasonably be due to the pure contribution by the ozone decrease in the Arctic stratosphere. The Student's $t$-test at two tails is used to test the significance level of the composite anomaly and difference.

\section{How Often Does the Arctic Ozone Loss Happen?}

\subsection{Verification of the Total Column Ozone Simulation in Early Spring}

Northern Hemisphere total column ozone distributions for the climatology in March at the time of an Arctic ozone loss event are shown in Figure 1. In early spring as the polar night ends and direct sunlight reaches the Arctic, the Arctic total column ozone usu-

(b) CMIP6 CASE (1993 MAR)

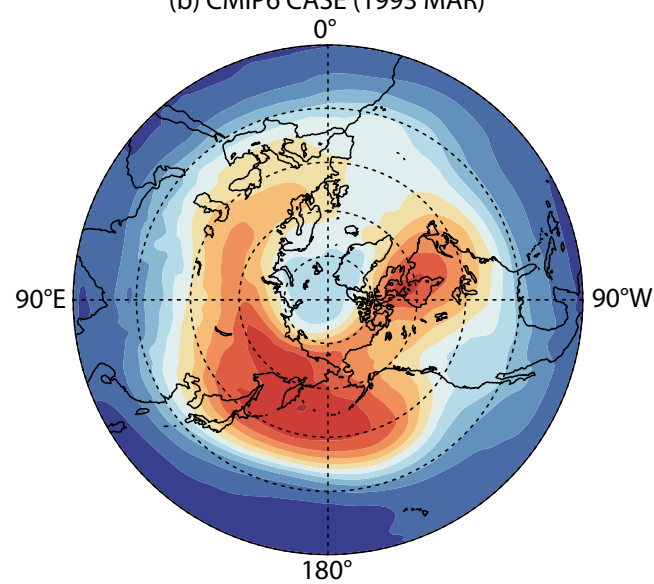

(d) ERA5 CASE (2011 MAR)

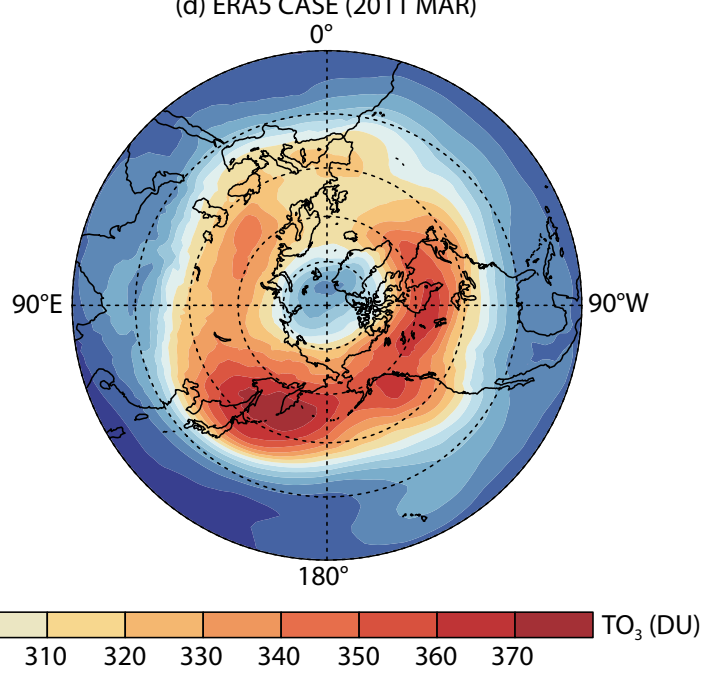

Figure 1. Distribution of the March total column ozone in the Northern Hemisphere extratropics (units: DU) for (a, c) long-term mean (climatology) and (b, d) Arctic ozone loss events from the ERA5 and the historical run from CESM2-WACCM. An ozone loss example is simulated in March 1993 from the first historical run by CESM2-WACCM (c). The observed Arctic ozone loss events occurred in March of 1997, 2011, and 2020; only the 2011 case is shown for an observational example (d). 
ally recovers to $>310 \mathrm{DU}$ in the polar region. Two maximum total ozone centers are evident in both CESM2-WACCM and ERA5 data (Figures 1a and 1c): one over the Sea of Okhotsk (>360 DU), the other over Baffin Island (>340 DU). The wave pattern of the climatological ozone is well reproduced by the model: the high lobes are over East Asia and East North America, and the relative lows are over Western Siberia and West North America. The tropospheric column total ozone profiles for typical Arctic ozone loss events are compared for CESM2-WACCM and ERA5 in Figure $1 \mathrm{~b}$ and $1 \mathrm{~d}$. Although the Northern Hemisphere total ozone in mid-tohigh latitudes is even anomalously higher, the ozone over the Arctic is extremely low during Arctic ozone loss events in both the model and ERA5. Previous studies have revealed that the Arctic total ozone loss is a consequence of weak dynamic transport of ozone-rich air into the Arctic and chemical loss due to the extremely cold state of the stratospheric polar vortex (Manney et al., 2020; Rao J and Garfinkel, 2020). Reproducibility of the ozone loss events by CESM2-WACCM verifies the quality of the model and the usability of the historical simulation for ozone loss events.

\subsection{Frequency of the Arctic Ozone Loss Events}

In the ERA5 reanalysis of data since 1979, three ozone loss events over the Arctic are identified (i.e., 1997, 2011, and 2020). Based on this limited record, an Arctic ozone loss event appears to occur approximately once in 14 years, on average, in the present-day cli- mate system. Using the long-term historical runs, in this subsection we revisit the questions of the frequency of simulated Arctic ozone loss events.

The time series of total column ozone anomalies over the Arctic in March, from 1850 to 2014, is shown in Figure 2 for three historical simulations by CESM2-WACCM. The Arctic ozone in early spring exhibits strong interannual variability; the standard deviation of March ozone is commonly around 20 DU in the three historical simulations. Such strong variability of the Arctic ozone in early spring is caused mainly by the large year-to-year variation of the stratospheric polar vortex. For example, the timing of the final warming can range from March in some years (early warming) to May in others (late warming) (Rao J and Garfinkel, 2020). Late final warmings have strong consequences for polar ozone loss, whereas early final warmings lead to a rapid recovery of the Arctic ozone due to the warm conditions in the Arctic stratosphere (Manney et al., 2020; Rao J and Garfinkel, 2020).

All major Arctic ozone loss events selected by using the 1.5 standard deviations threshold are shown in Table 1. Nine such Arctic ozone loss events are identified in the 165-yr simulation for the first historical run, suggesting an occurrence frequency of approximately every 18 years. Similarly, the average frequency is once every 12 years for the second run and once every 18 years for the third run. A total of 32 Arctic ozone loss events are selected from
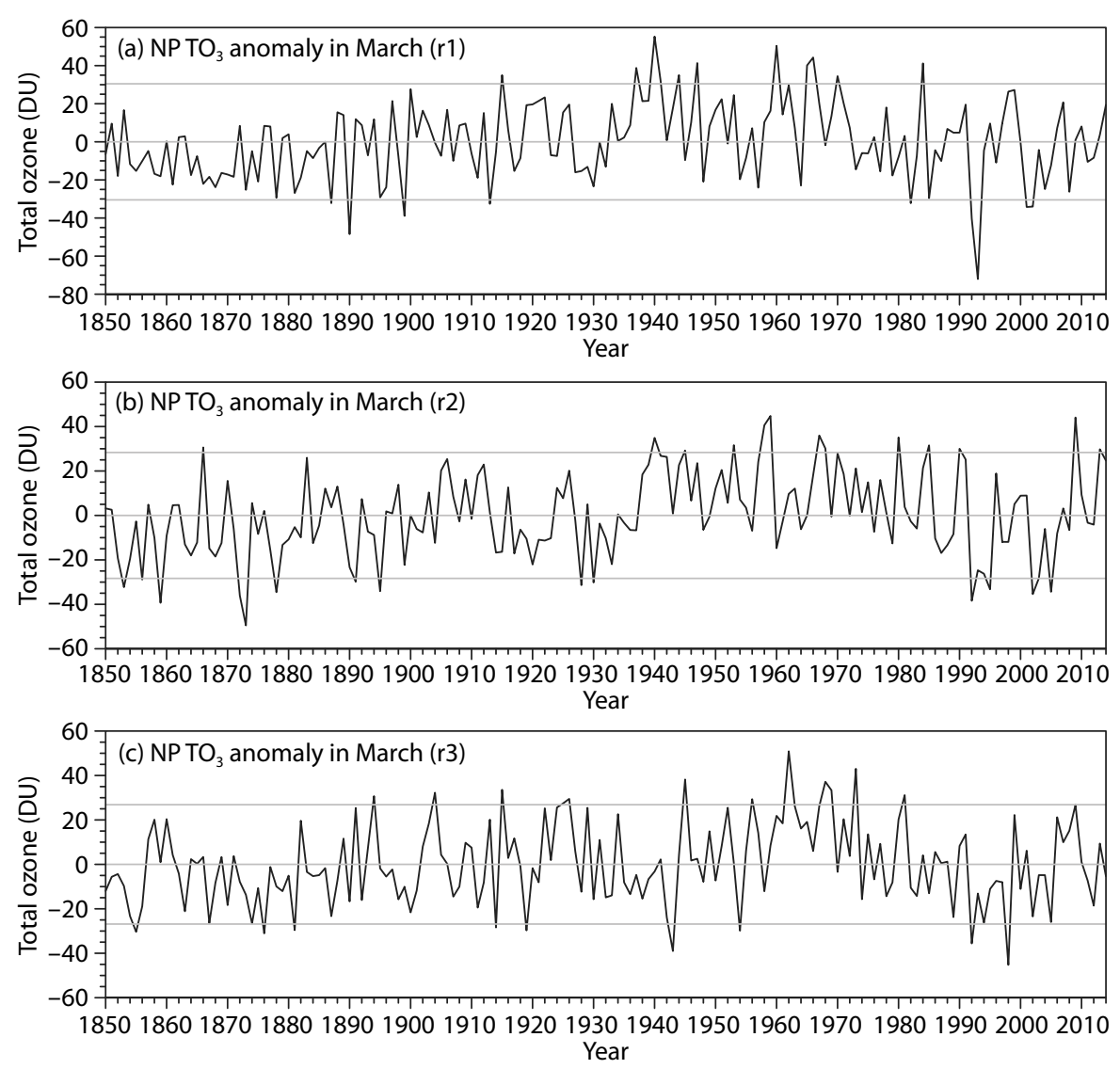

Figure 2. Time series of Arctic total column ozone content anomalies averaged over $65-90^{\circ} \mathrm{N}$ (units: DU) in March from 1850 to 2014 (model year) in three historical runs by CESM2-WACCM. Reference lines for each historical run are zero and \pm 1.5 times that run's standard deviation of the March total ozone. 
Table 1. Selected March Arctic ozone loss events in each historical run by CESM2-WACCM.

\begin{tabular}{|c|c|c|c|}
\hline Historical run & Selection standard & Sample & Sample size \\
\hline r2 & \multirow{2}{*}{$\begin{array}{l}\text { Within each historical run, } \\
\text { anomalies are defined by a decrease of } \\
\text { at least } 1.5 \text { standard deviations from } \\
\text { the long-run average of total column } \\
\text { ozone over the Arctic }\end{array}$} & $\begin{array}{l}1853,1856,1859,1872,1873,1878,1891 \\
1895,1928,1930,1992,1995,2002,2005\end{array}$ & 14 \\
\hline r3 & & 1855, 1876, 1881, 1914, 1919, 1943, 1954, 1992, 1998 & 9 \\
\hline
\end{tabular}

the three simulations (495 years in total). The mean frequency of the ozone loss events in CESM2-WACCM data is thus roughly every 15 years, consistent with the empirical observations (Newman et al., 1997; Manney et al., 2020).

\section{Stratosphere-Troposphere Coupling During Anomalous Arctic Ozone Events}

\subsection{Evolution of the Arctic Ozone and Stratosphere}

The spatial distribution of total column ozone anomalies in the extratropics from January to May is shown in the first row of Figure 3. The Arctic ozone loss begins in winter and reaches its maximum in March (-60 DU); meanwhile the ozone in the North Pacific is anomalously higher throughout the winter to early spring (Figures 3 a1-c1). Ozone loss in the Arctic does not occur suddenly, but is an accumulation of ozone depletion in the previous months. The early spring Arctic ozone loss is followed by a gradual recovery of total atmospheric ozone from April onwards (Figures 3d1 and e1). Although the negative ozone anomalies in April and May gradually diminish, the ozone reduction is still significant in May. Due to the large sample size from the three historical simulations, the Arctic ozone anomalies are significant at the $95 \%$ confidence level from January to May. The total ozone over the tropical Pacific is also shown to decrease from January to May, which might be related to the weakened upwelling in the tropics associated with the suppressed Brewer-Dobson circulation during strong polar vortex events (Roscoe, 2006; Butchart, 2014; Shi CH et al., 2018; Rao J et al., 2019). In April and May, a decrease in the total ozone might contribute partially to a change in the stratospheric temperature.

The evolution of the temperature anomalies at $50 \mathrm{hPa}$ during Arctic ozone loss events is shown in the second row of Figure 3. The cold anomalies in March and previous winter months are centered around the polar region with a maximum amplitude of $>2.5 \mathrm{~K}$. In midlatitudes poleward of $60^{\circ} \mathrm{N}$, warm anomalies dominate. The persisting cold conditions in the Arctic stratosphere in January and February create a prerequisite meteorological condition for Arctic ozone loss. Namely, in winter and early spring, ozone loss is coupled to strong and cold polar vortices, and the warm anomalies in midlatitudes denote a positive NAM pattern in the Northern Hemisphere (Figures 3a2-c2). The annular mode is extremely strong when the Arctic ozone loss is coupled with the extreme polar vortex (Randel and Wu F, 1999; Hu YY and Xia Y, 2013). In the following April, the stratospheric temperature response is zonally fairly asymmetric (Figure 3d2). Significant temperature anomalies in the polar region nearly disappear in April, but warm anomalies over the North Pacific still remain. The regional warm anomalies $(1.25 \mathrm{~K})$ are a lagged response to an increase in the local total ozone in preceding months and are not explained by the concur- rent ozone anomalies. In May the warm anomalies finally move to the Arctic, and the stratospheric temperature anomalies in low-tomid latitudes are dormant (Figure 3e2).

\subsection{Evolution of the Tropospheric and Near Surface Response}

Similarly, the evolution of the composite temperature anomalies at $500 \mathrm{hPa}$ from January to May is shown in the third row of Figure 3 for Arctic ozone loss events. The temperature anomalies in the troposphere are nearly out of phase with those in the stratosphere. In particular, the Arctic middle troposphere is covered with warm anomalies from January to March (Figures 3a3-c3). In the Pacific sector, such an out-of-phase coupling between the troposphere and stratosphere can be explained by the ozone distribution. Specifically, in the North Pacific, the total column ozone is anomalously abundant, absorbing more ultraviolet radiation in the stratosphere. As a result, solar radiation reaching the troposphere decreases, corresponding to local cold anomalies; in high latitudes, less ozone allows more solar radiation to reach the troposphere and induce local warm anomalies (Xie F et al., 2008; Xia $Y$ et al., 2018). There are three warm anomaly centers in high latitudes, located over Alaska, Greenland, and the North Atlantic. The out-of-phase troposphere-stratosphere temperature coupling can also be explained by the Ertel's potential vorticity change (Edmon et al., 1980). The tropospheric response in April and May is not as evident as in January-March except for patches of warm anomalies in high continental latitudes.

The composite surface temperature anomalies from January-May for the Arctic ozone loss events are shown in the last row of Figure 3. In winter months preceding Arctic ozone loss events, the North Eurasian is anomalously cold while the Arctic is warm from the Bering Strait across the Western US to Northern Canada and Greenland (Figures 3a4 and b4). The cold anomalies over Northern Eurasia gradually diminish, and the warm anomalies develop and cover midlatitudes over North America from January to February. It is noted that warm anomalies develop over the Northeastern Pacific at the surface, whereas such warm anomalies are further equatorward and more zonally uniform at $500 \mathrm{hPa}$. The Arctic warm state persists until May and the cold anomalies over the Central North Pacific do not disappear until May (Figures 3c4 and d4). In short, Arctic ozone loss events exhibit significant lagged impact on the continental surface temperature at high latitudes and on the Pacific temperature.

Overall, the composite temperature anomalies associated with Arctic ozone loss events are nearly out of phase between the subpolar region and the midlatitudes. In addition, the tropospheric and stratospheric temperature anomalies are dynamically coupled in opposite phase. 

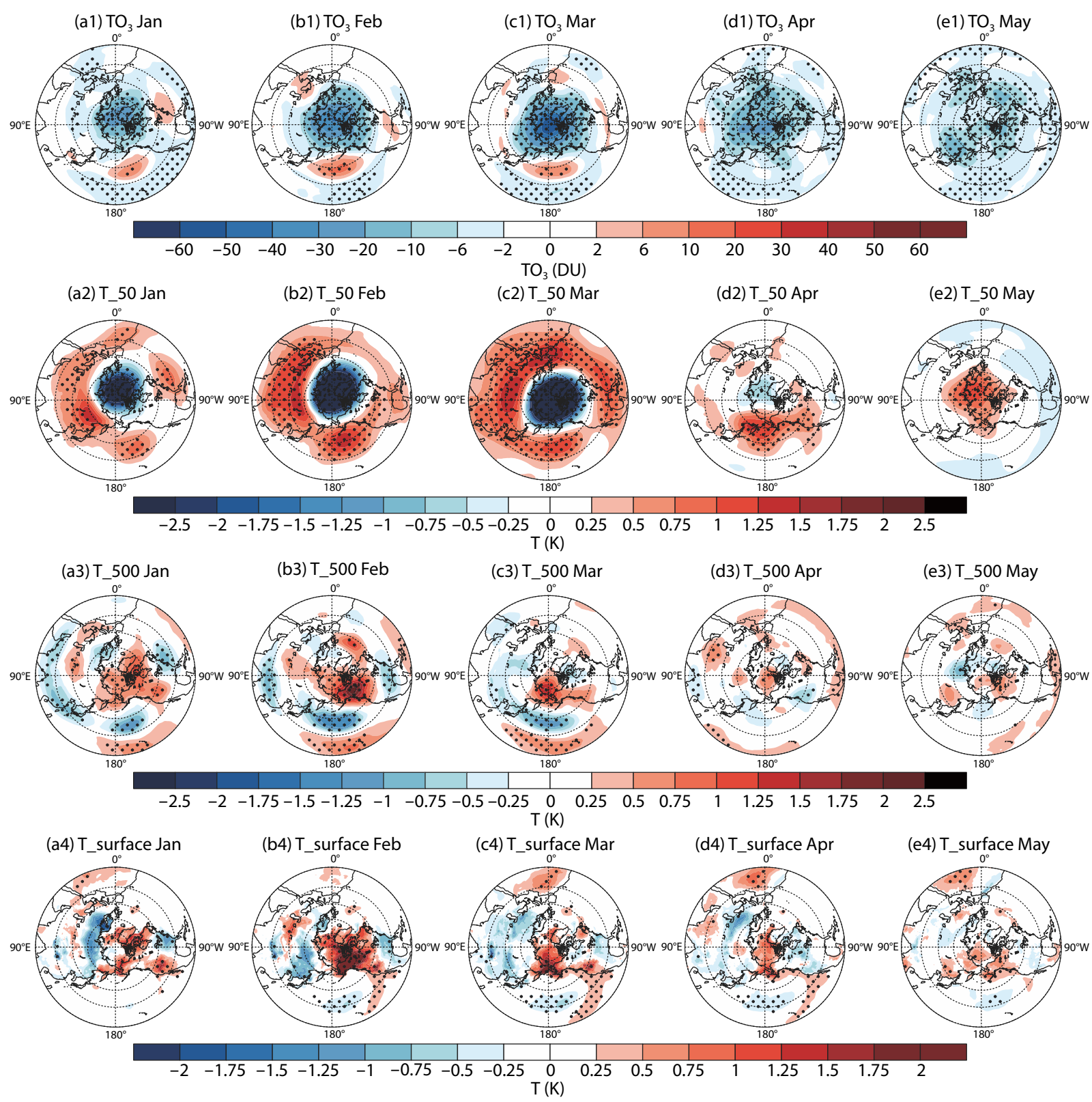

Figure 3. Composite evolution of the Northern Hemisphere extratropical total column ozone anomalies (units: DU; first row), 50-hPa air temperature anomalies (units: $\mathrm{K}$; second row), 500-hPa air temperature anomalies (units: $\mathrm{K}$; third row), and surface temperature anomalies (units: $\mathrm{K}$; last row) from January to May for 32 Arctic total ozone loss events in early spring. The dotted regions mark the composite total column ozone or air temperature anomalies at the $95 \%$ confidence level.

\section{Separating the Direct Impact of Arctic Ozone Loss from the Impact of the Strong Polar Vortex}

\subsection{Evolution of the Stratospheric Polar Vortex and Ozone}

It is well documented that Arctic spring ozone depletion is associated with a strong and cold stratospheric polar vortex over the Arctic and is often accompanied by positive NAM/North Atlantic Oscillation (NAO) polarity in early spring (Thompson and Solomon, 2002; Previdi and Polvani, 2014; Solomon et al., 2014). The observed impact of the Arctic ozone loss might be due to the dynamical influence of the strong polar vortex. To determine the direct impact of Arctic ozone loss, the atmospheric response to the strong polar vortex should be eliminated from the composite.
Two samples are selected from the three historical simulations: one group of strong polar vortex events coupled to Arctic ozone loss, and a second group that were uncoupled to an Arctic ozone loss. The difference between the two samples would represent the impact of Arctic ozone variations alone - if we assume that the superimposed impacts of the ozone variation and the strong polar vortex are linear.

The time series of the polar cap height at $10 \mathrm{hPa}$ in March is shown in Figure 4 as a representative metric of the stratospheric polar vortex. Comparing the Arctic ozone loss (red curves) and the polar cap height (black curves) in March, all Arctic ozone loss events are coupled with the strong polar vortex in the three his- 

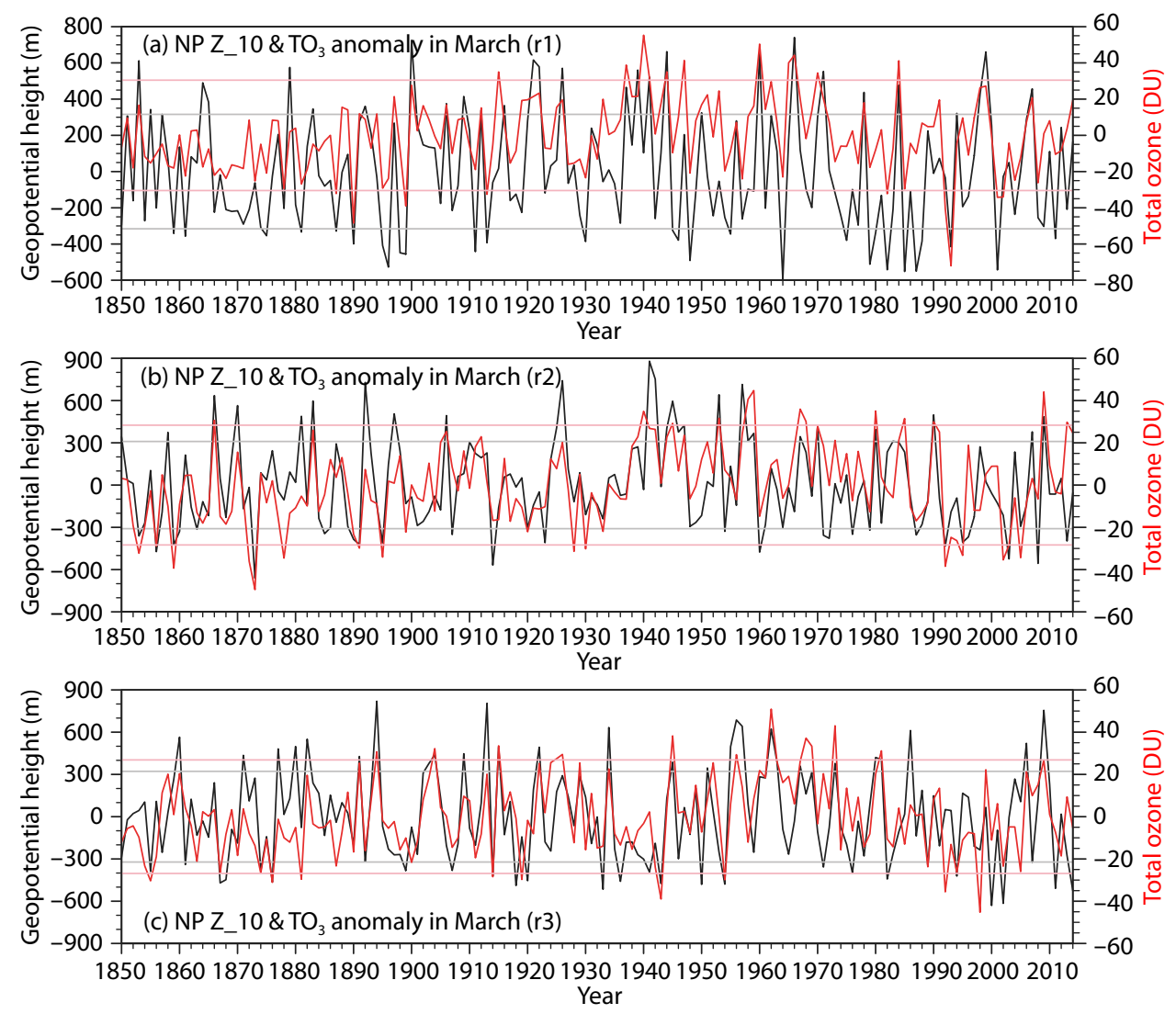

Figure 4. Time series of the polar cap height anomalies averaged over $65-90^{\circ} \mathrm{N}$ at $10 \mathrm{hPa}$ (black curves; units: $\mathrm{m}$; left ordinate) and Arctic total column ozone content anomalies averaged over $65-90^{\circ} \mathrm{N}$ (red curves; units: DU; right ordinate) in March from 1850 to 2014 (model year) in three historical runs by CESM2-WACCM. Black reference lines for each historical run are \pm 1.0 standard deviation of that run's polar cap height in March. Red reference lines are \pm 1.5 times the run's standard deviation of the Arctic total ozone in March.

torical simulations. Therefore, the model assumes that a strong and cold stratospheric polar vortex is a requisite condition for ozone loss in the Arctic, consistent with the observational data (Manney et al., 2020; Rao J and Garfinkel, 2020, 2021). However, not all strong polar vortex events are accompanied with Arctic ozone loss.

Using one standard deviation from the average March polar height as the threshold, strong polar vortex events are selected from the three historical runs (Table 2). It is found that 26-28 strong polar vortex events appear in early spring in each $165-\mathrm{yr}$ simulation; in the model, roughly $40 \%$ of the instances of strong polar vortex are accompanied by Arctic ozone loss. Such a percentage in CESM2-WACCM is consistent with the reanalysis, which shows that 7 strong polar vortex events appear in March from
1979-2020, of which three (43\%) were coupled with Arctic ozone loss (Huang JL et al., 2017; Rao J and Garfinkel, 2020, 2021; Zhang YL et al., 2021).

Some modeling and observational studies have found that stratosphere-troposphere coupling is strong in years with very low and very high ozone levels (Calvo et al., 2015; Ivy et al., 2017; Stone et al., 2019). However, other studies have concluded that simulations using prescribed ozone observations do not exhibit a strong stratosphere-troposphere response (Smith and Polvani, 2014). The so-called observed stratosphere-troposphere response to Arctic ozone loss may be a coincidence due to the combined effect of ozone depletion forced out by a strong polar vortex and the strong polar vortex itself (Harari et al., 2019). The composite evolutions of the height anomalies at $10 \mathrm{hPa}$ for strong polar vor-

Table 2. Selected strong stratospheric polar vortex events in early spring in each historical run by CESM2-WACCM.

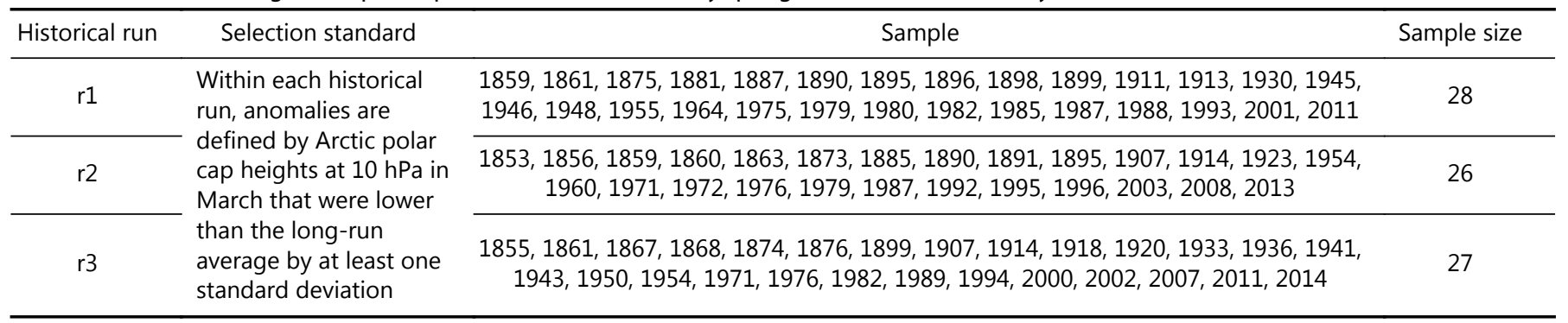




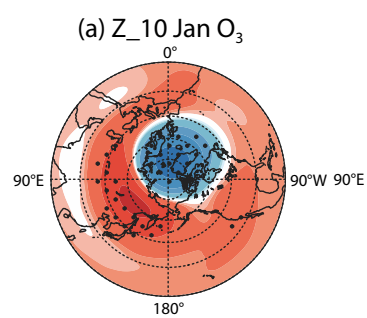

(f) Z_10 Jan (b) Z_10 $\mathrm{Feb} \mathrm{O}_{3}$

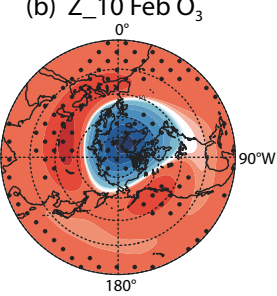

(g) Z_10 Feb

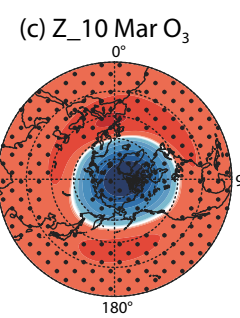

(h) Z_10 Mar

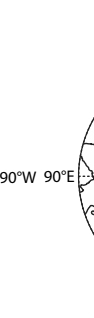

$0^{\circ}$ (d) Z_10Apr $\mathrm{O}_{3}$

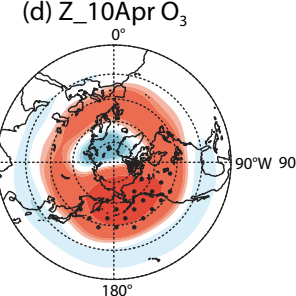

(i) Z_10 Apr (e) Z_10 May $\mathrm{O}_{3}$

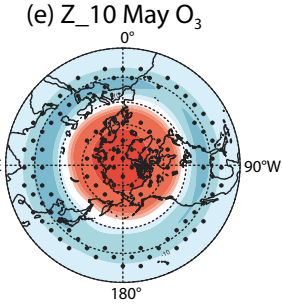

(j) Z_10 May

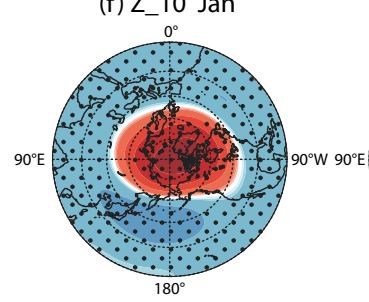

k) (a) $-(f)$

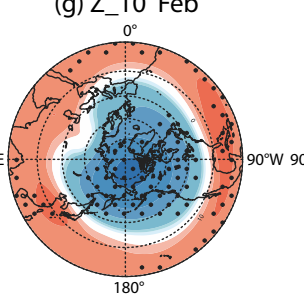

(l) (b) $-(\mathrm{g})$
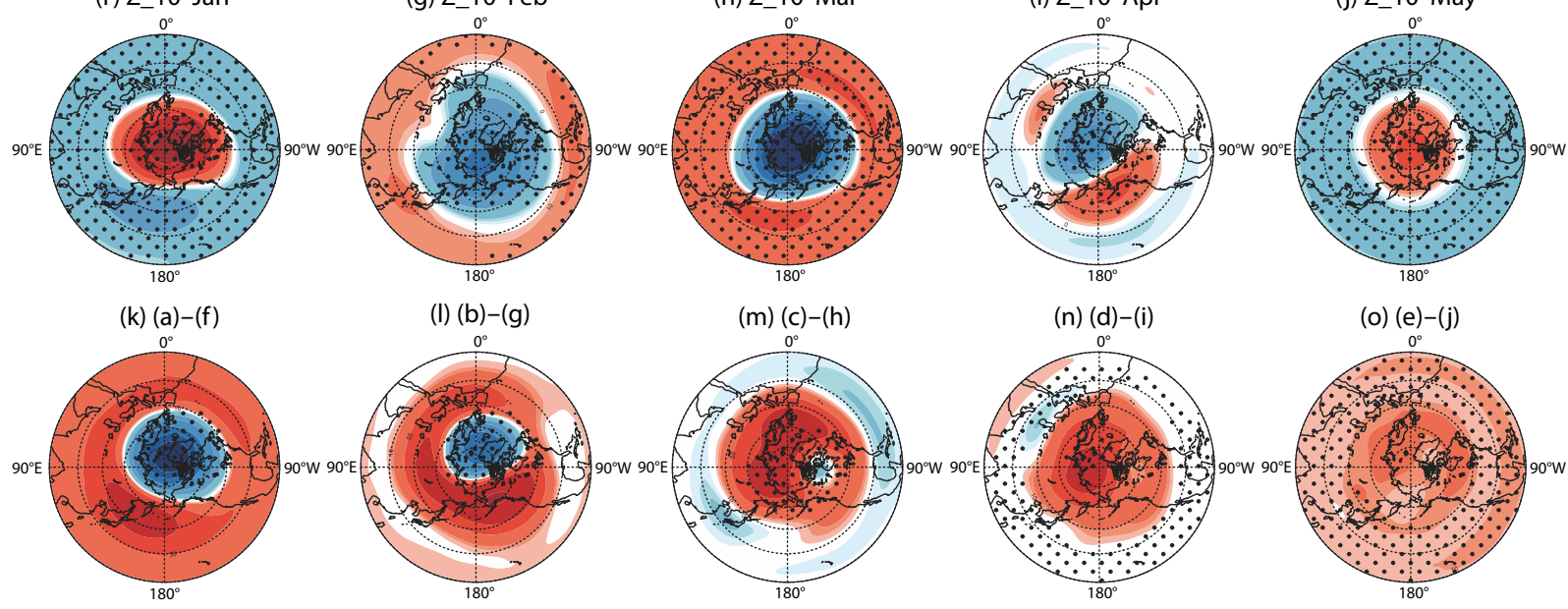

(m) (c)-(h)

(n) (d) $-(\mathrm{i})$

(o) (e)-(j)

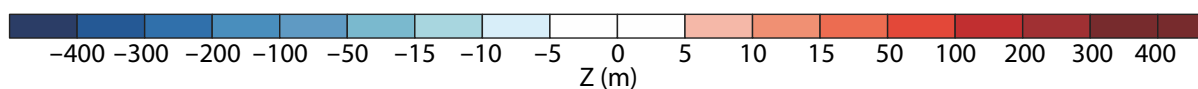

(n) $\begin{gathered}(\mathrm{d}) \\ 0^{\circ}\end{gathered}$

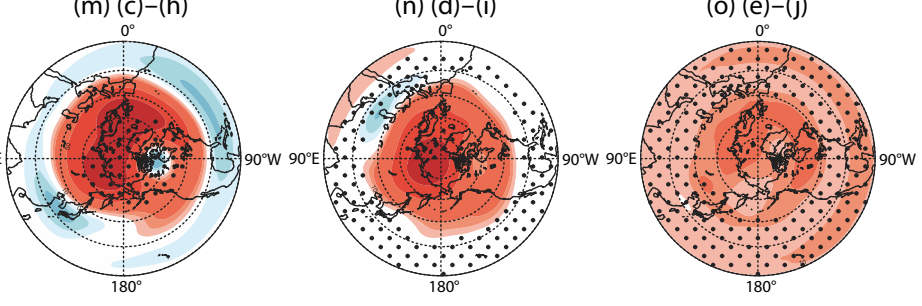

Figure 5. Composite evolution of the height anomalies at $10 \mathrm{hPa}$ (shadings; units: $\mathrm{m}$ ) in Northern Hemisphere extratropics from January to May for (top) strong stratospheric polar vortex events coupled to Arctic ozone loss in March (i.e., Arctic ozone loss events) and (middle) strong stratospheric polar vortex events uncoupled to Arctic ozone loss in March. (Bottom) the difference of the height anomalies from January to May between Arctic ozone loss events and strong polar vortex events uncoupled to Arctic ozone loss in March, as a representative of the impact of Arctic ozone loss. The dotted regions mark the composite height anomalies or differences at the $95 \%$ confidence level.

tex events coupled with ozone loss and uncoupled with ozone loss are shown in Figure 5 (top and middle rows, respectively). The strong polar vortex events coupled with ozone loss have a very long lifetime, persisting from January to March. The strong polar vortex state begins in early winter and persists into early spring when it is coupled with Arctic ozone loss (Figures 5a-5e). Without the Arctic ozone loss, the polar vortex is usually weak in early winter and changes to the strong state in late winter and early spring (Figures $5 f-5 j$ ).

The annular band pattern of the positive height anomalies at midlatitudes contrasts with the negative height anomalies in the polar region, which project to a positive phase of the NAM. The stratospheric NAM is significantly stronger during an Arctic ozone loss than during the average strong polar vortex event uncoupled to Arctic ozone loss (Figures 5k-5o). As a result, the NAM evolves quickly in the positive phase if an Arctic ozone loss event participates, whereas the NAM develops slowly from the negative phase in January to the positive in February when strong polar vortex events occur without Arctic ozone loss. For both conditions, the NAM is reversed in May (Figures $5 e$ and $5 \mathrm{j}$ ). During Arctic ozone loss events, the ozone is anomalously abundant over the North Pacific, so the local positive height anomalies are stronger than in the general case of strong polar vortex events by the process of diabatic heating (Figures $5 \mathrm{~d}$ and $5 \mathrm{i}$ ). The positive height anom- alies at high latitudes expand to cover nearly the entire Arctic (see Figure $8 \mathrm{~d}$ ), leading to early, rapid, reversal of the NAM (Figures $5 k-50)$.

The composite evolutions of total column ozone anomalies observed when strong polar vortex events are coupled and uncoupled to ozone loss are shown in the first two rows of Figure 6. The first row (Figures 6a-6e) reveals that total column ozone associated with strong polar vortex events coupled with ozone loss gradually decreases from January to March, denoted by negative ozone anomalies. The second row (Figures $6 \mathrm{~g}-6 \mathrm{j}$ ), presenting strong polar vortex events without ozone loss, reveals that the ozone anomalies are much weaker; from February to May, only scattered positive ozone anomalies are observed. The third row presents the ozone difference between cases of strong polar vortex events coupled with ozone loss and those uncoupled with ozone loss further confirms a huge ozone depletion in the winter and spring ozone loss (Figures 6k-6o).

The composite zonal-mean air temperature anomalies and the temperature anomalies explained by solar radiation in March and April are shown in Figures $7 \mathrm{a}$ and $7 \mathrm{~b}$, for strong polar vortex events coupled to ozone loss and in Figures $7 c$ and $7 d$, for those uncoupled to ozone loss. After the vernal equinox, solar radiation gradually reaches the polar region, which together with the ozone loss can lead to less stratospheric absorption of the shortwaves. In 


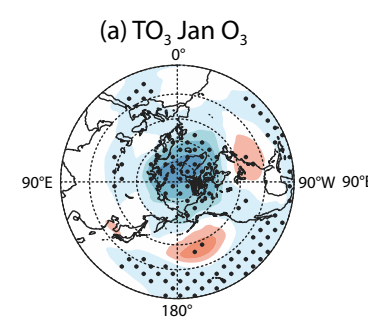

(f) $\mathrm{TO}_{3}$ Jan

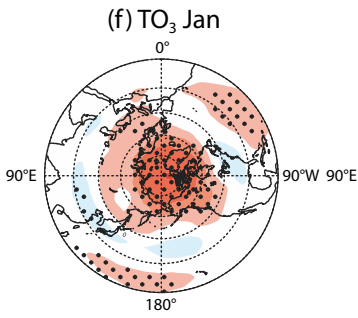

(k) (a)-(f) (b) $\mathrm{TO}_{3} \mathrm{Feb} \mathrm{O}_{3}$

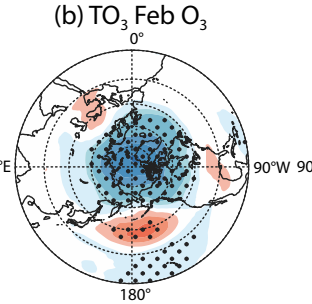

(g) $\mathrm{TO}_{3} \mathrm{Feb}$

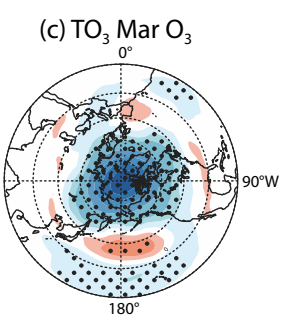

(h) $\mathrm{TO}_{3} \mathrm{Mar}$

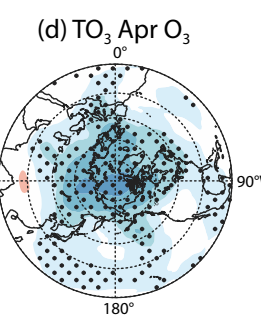

(i) $\mathrm{TO}_{3} \mathrm{Apr}$

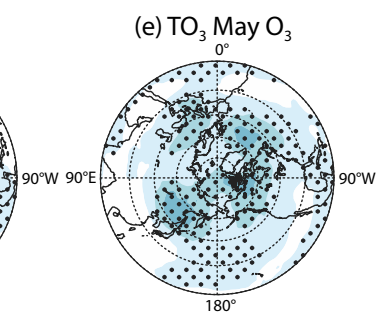

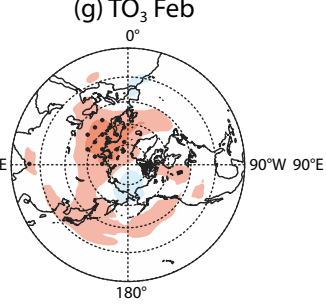

(l) (b)-(g)

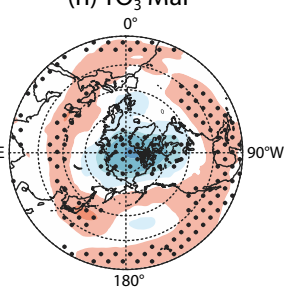

(m) (c) $-(\mathrm{h})$
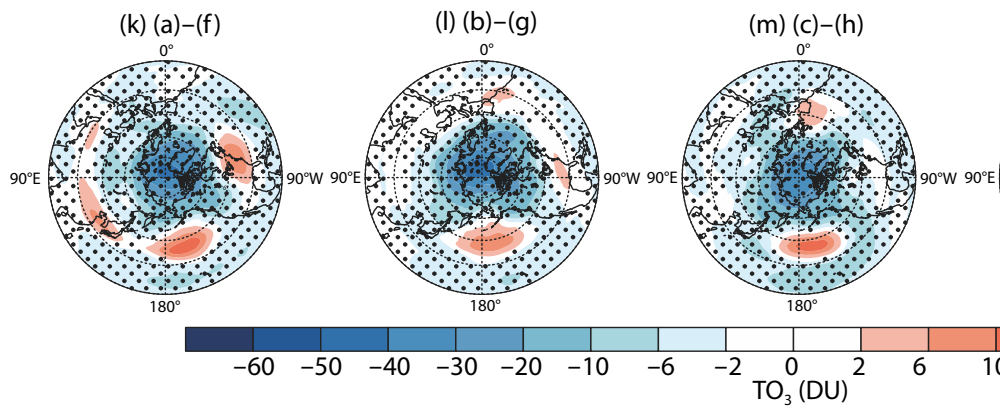

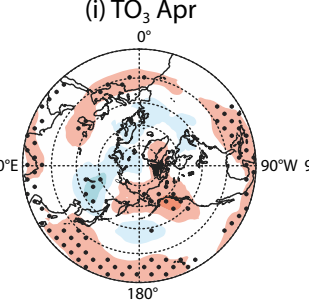

(n) (d)-(i) (j) $\mathrm{TO}_{3}$ May

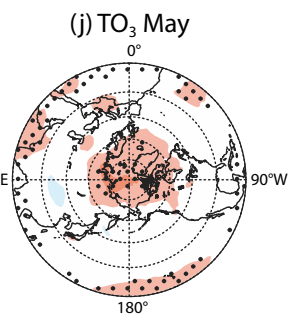

(o) (e)-(j)

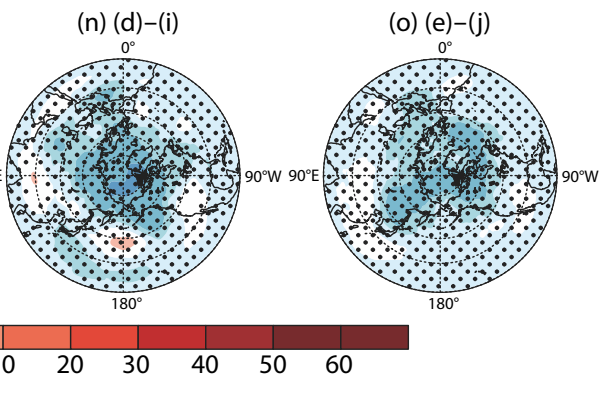

Figure 6. Composite evolution of the total column ozone anomalies (shadings; units: DU) in Northern Hemisphere extratropics from January to May for (top row) strong stratospheric polar vortex events coupled to Arctic ozone loss in March (i.e., Arctic ozone loss events) and (middle row) strong stratospheric polar vortex events uncoupled to Arctic ozone loss in March. (Bottom row) Differences between top row and middle row, e.g., the total column ozone differences between the two sets of cases. The dotted regions mark composite anomalies or differences at the $95 \%$ confidence level.

(a) $\mathrm{T} \mathrm{Mar}_{3}$

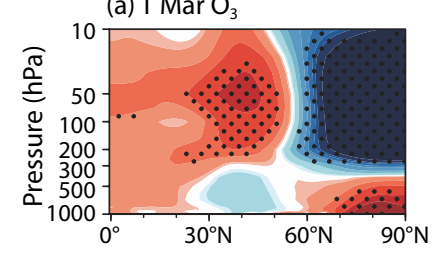

(e) T_SR Mar $\mathrm{O}_{3}$

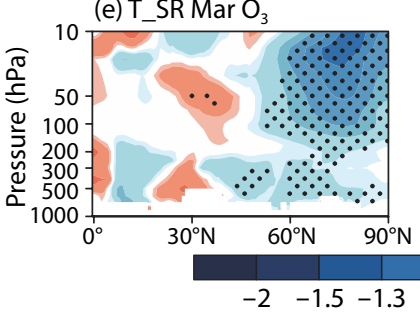

(b) $\mathrm{T} \mathrm{AprO}_{3}$

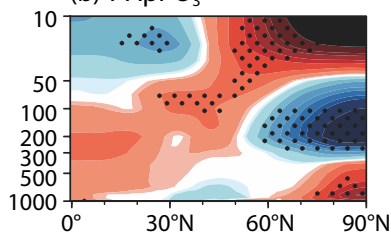

(f) T_SR Apr O (c) T Mar

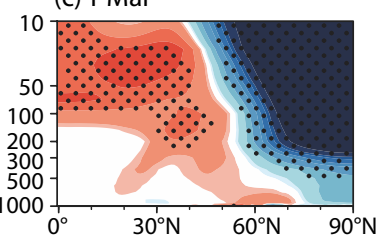

(g) T_SR Mar (d) T Apr

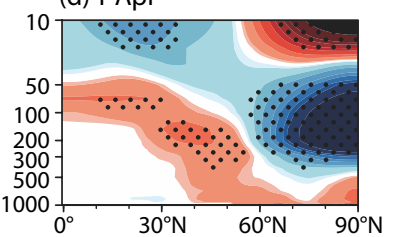

(h) T_SR Apr

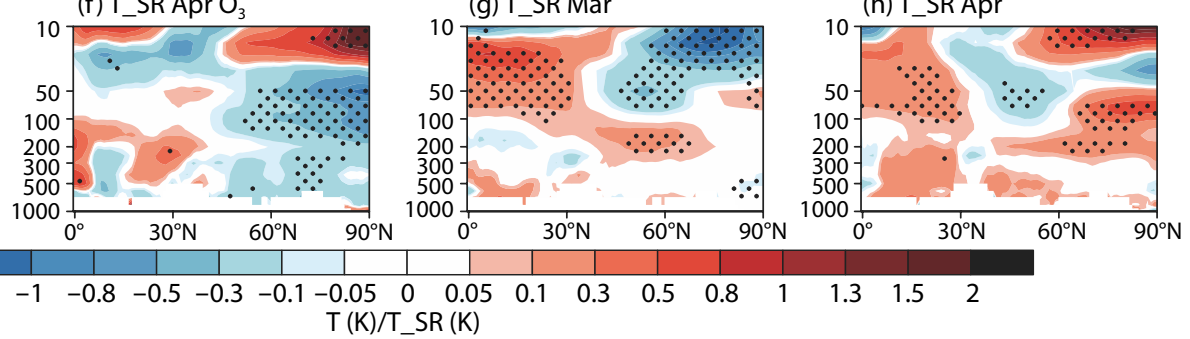

Figure 7. Composite zonal-mean air temperature anomalies (shadings; units: $\mathrm{K}$ ) in March and April during (a, b) strong stratospheric polar vortex events coupled Arctic ozone loss in March (i.e., Arctic ozone loss events) and (c, d) strong stratospheric polar vortex events uncoupled to Arctic ozone loss in March. (e-h) As in (a-d) but for the temperature anomalies explained by solar radiation in March and April. The dotted regions mark the composite anomalies or differences at the $95 \%$ confidence level.

March, the ozone loss and the negative temperature anomalies reach their climax in the Arctic stratosphere (Figure 7a). The negative temperature anomalies in the polar region are both dynamically related to the weakened Brewer-Dobson circulation (Rao J and Garfinkel, 2020, 2021) and thermodynamically associated with the decrease of absorbed shortwaves (Figure 7e). It is estimated that the ozone loss contributes directly roughly $-0.8 \mathrm{~K}$ to the $(-2.0 \mathrm{~K})$ total cold anomalies over the Arctic, by modifying absorp- 
tion of solar radiation. As ozone gradually recovers from the upper stratosphere in April, the cold center descends to the lower stratosphere (Figure 7b). In April, ozone loss contributes directly approximately $-0.5 \mathrm{~K}$ (Figure $7 \mathrm{f}$ ) to the total $(-1.5 \mathrm{~K})$ cold anomalies in the Arctic lower stratosphere.

In contrast, when strong polar vortex events occur uncoupled with Arctic ozone loss, the cold anomalies in the Arctic stratosphere are produced more dynamically (Figure 7c). Namely, the cold anomalies in the lower stratosphere over the Arctic are not explained primarily by shortwave absorption, although above $50 \mathrm{hPa}$ the reduced absorption of shortwaves does explain a small part of the cold anomalies (Figure 7g). In April, the cold anomaly center descends to the lower stratosphere over the Arctic, but without the ozone loss the solar radiation absorption is not reduced (Figure 7h). Therefore, the thermodynamic process does not explain the persistent cold anomalies in the Arctic stratosphere for strong polar vortex events uncoupled with ozone loss.

\subsection{Separating the Impact of Arctic Ozone Loss on the Troposphere and the Surface}

For strong polar vortex events coupled and uncoupled to Arctic ozone loss, the stratospheric NAM evolution has been shown to evolve differently. The evolution of the temperature anomalies at $500 \mathrm{hPa}$ are compared in Figure 8 for both conditions. After the winter solstice, the polar night gradually shortens and sunlight can reach some high latitudes. Therefore, when ozone loss causes reduced absorption of solar radiation in the stratosphere over the Arctic Circle, more solar radiation can reach the troposphere, corresponding to a warming signal over the Arctic and Canada in winter (Figures $8 \mathrm{a}$ and $8 \mathrm{~b}$ ). The North Pacific is covered with more ozone in the stratosphere, which absorbs more solar radiation, so less solar radiation reaches the troposphere, explaining the local cold anomalies. Such a temperature pattern develops in the extratropics from January to February. The warm anomalies over the Arctic gradually shrink to the Bering Strait in March and finally disappear in spring (Figures $8 c-8 e$ ).

For strong polar vortex events without Arctic ozone loss, the $500 \mathrm{hPa}$ temperature evolution is very different; the polar response displays a quasi-barotropic structure from the stratosphere to the troposphere. The Arctic troposphere is warm in January, corresponding to a weak polar vortex (Figure 8f). As the stratospheric polar vortex strengthens in late winter and early spring, the troposphere is also anomalously cold in the Arctic, in contrast to the warm response in midlatitudes (Figures $8 \mathrm{~g}$ and $8 \mathrm{~h})$. The cold response is reversed in April and May as the strong polar vortex recovers to its normal state (Figures $8 \mathrm{l}$ and $8 \mathrm{j}$ ). The stratosphere-troposphere coupling is different during events of Arctic ozone loss from the coupling during strong polar vortex events; the ozone loss seems to cancel the positive NAM-like re-

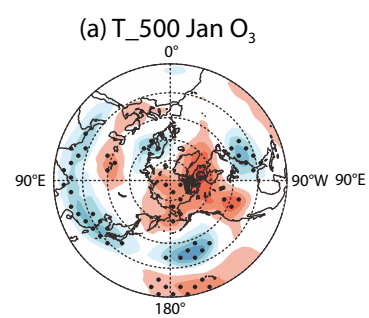

(f) T_500 Jan

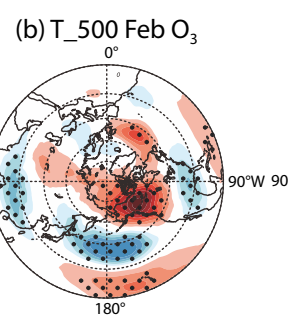

(g) T_500 Feb

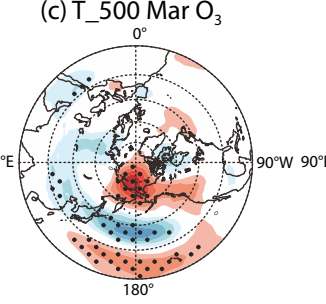

(h) T_500 Mar

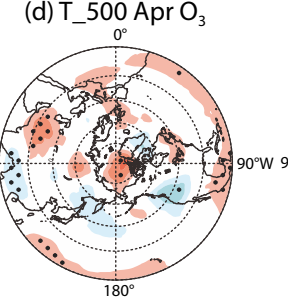

(i) T_500 Apr

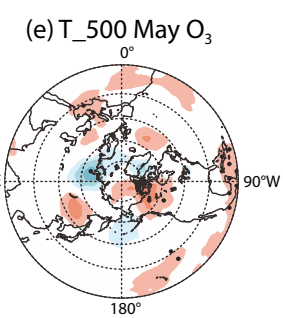

(j) T_500 May

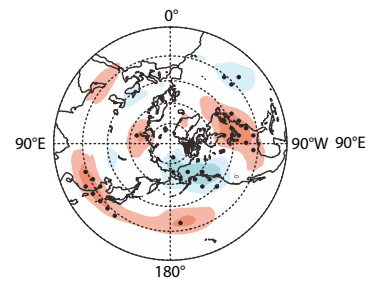

(k) (a)-(f)

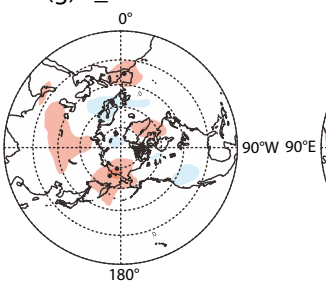

(l) (b) $-(\mathrm{g})$

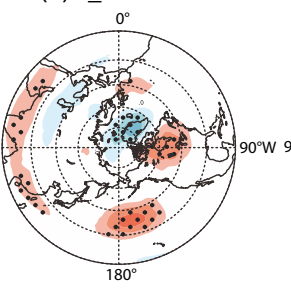

(m) (c)-(h)

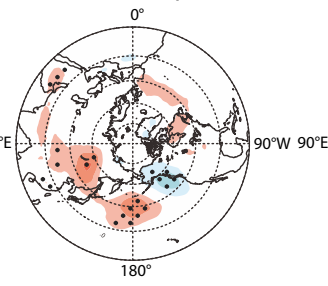

(n) (d)-(i)

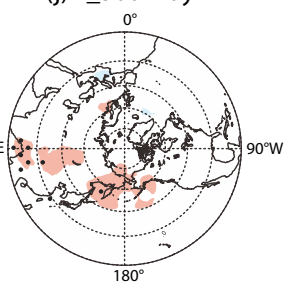

(o) (e)-(j)

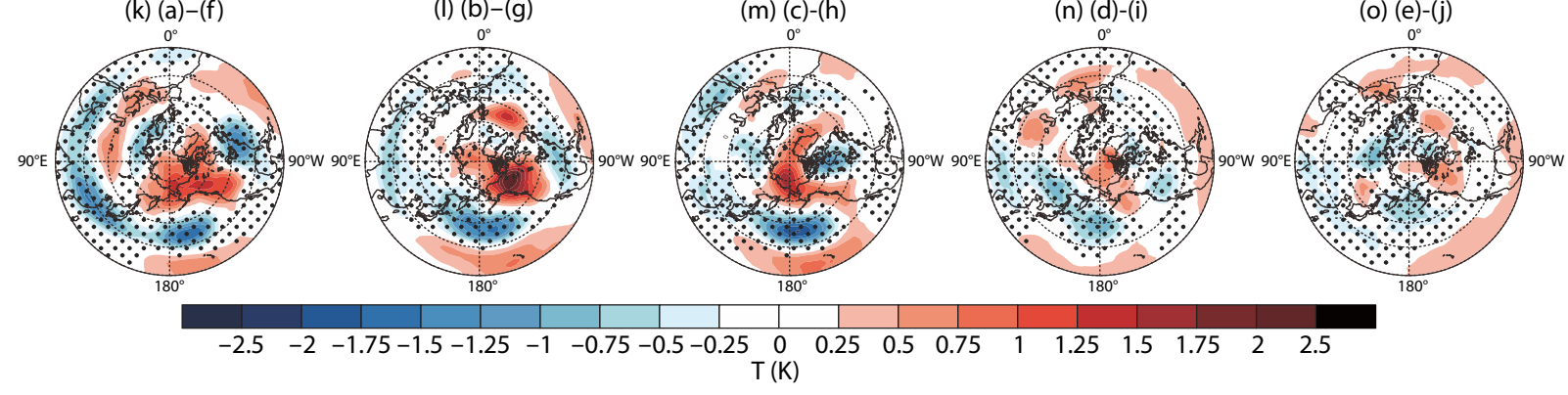

Figure 8. Composite evolution of the air temperature anomalies at $500 \mathrm{hPa}$ (shadings; units: K) in Northern Hemisphere extratropics from January to May for (top) strong stratospheric polar vortex events coupled to Arctic ozone loss in March (i.e., Arctic ozone loss events) and (middle) strong stratospheric polar vortex events uncoupled to Arctic ozone loss in March. (Bottom) the difference between the two cases. The dotted regions mark the composite anomalies or differences at the $95 \%$ confidence level. 
sponse in the troposphere as seen from the difference between the two conditions (Figures $8 \mathrm{k}-80$ ). The strong positive NAM response associated with strong polar vortex in late winter and early spring is replaced by the warm anomalies over the Arctic if the ozone is lost, and the quick transition of the NAM sign associated with strong polar vortex is also not seen if ozone is lost.

To extract the direct impact of ozone loss on the near surface, in Figure 9 we show the surface temperature response to Arctic ozone loss and to the strong polar vortex. The warm response over the Bering Strait, western US, and Greenland during Arctic ozone loss events (Figures 9a-9c) is significantly larger than during the strong polar vortex (Figures $9 f-9 h$ ). The coverage of warm signals gradually shrinks in spring for both conditions (Figures $9 \mathrm{~d}$ and 9e; $9 \mathrm{i}$ and $9 \mathrm{j}$ ). The pure impact of the ozone loss is represented by the difference between the two conditions and is most significant and evident in Eurasia. The Arctic ozone loss can reverse the warm anomalies over Eurasia associated with positive NAM to the cold (Figures 9k-9o). The composite results also confirm that the warm Arctic and Northeast Pacific is related to Arctic ozone loss when more solar radiation reaches the surface, consistent with the case study by Smyshlyaev et al. (2021).

\section{Summary and Discussion}

Unlike the Antarctic "ozone hole" event that has occurred every spring since the 1980s, anomalous Arctic ozone loss events, as defined above, are observed to occur once every fourteen or fifteen years. Using historical simulations from a state-of-the-art coupled climate-chemistry model, CESM2-WACCM, we use a large sample size to separate a possible pure impact of the Arctic ozone loss from the influence of the strong polar vortex. The long-term mean state and frequency of Arctic ozone loss events in the historical runs by CESM2-WACCM highly agree with the ERA5 reanalysis. In the reanalysis, the climatological extratropical total ozone is found to be most abundant over East Asia in March, which is well reproduced by CESM2-WACCM. In both the reanalysis and the model, the Arctic ozone in March does not recover during the loss with the ozone minimum center over the North Pole. The high agreement between of CESM2-WACCM and observed Arctic ozone loss patterns suggests significant confidence in the composite results.

The composite Arctic ozone loss gets maximized in early spring, but the negative ozone anomalies over the Arctic develop in winter when the stratospheric polar vortex persists strong and cold for an extended period. The Arctic ozone loss is accompanied by ozone increase in midlatitudes, with its maximum center located over the Central North Pacific in late winter and early spring. The ozone pattern is consistent with the temperature anomaly distribution: warm (cold) regions in the stratosphere are covered with high (low) ozone. However, the temperature response to the ozone loss displays a warm-Arctic/cold-Pacific pattern in the troposphere from winter to spring. The Arctic warming

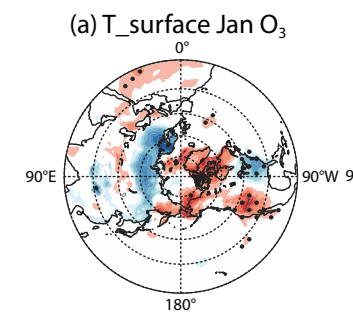

(f) T_surface Jan

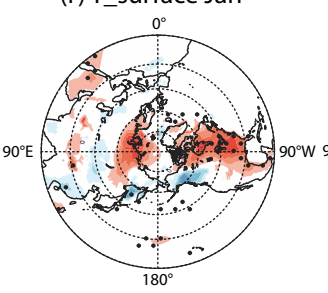

(k) (a)-(f)

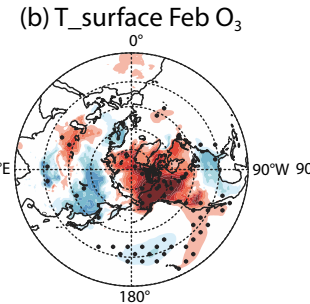

(g) T_surface Feb

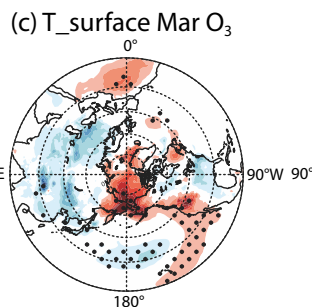

(h) T_surface Mar

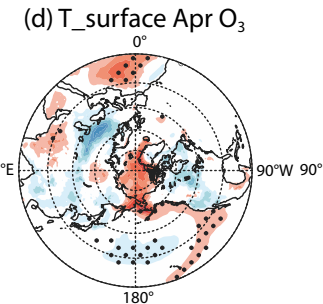

(i) T_surface Apr

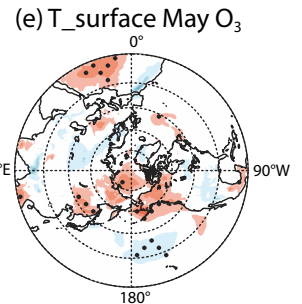

(j) T_surface May

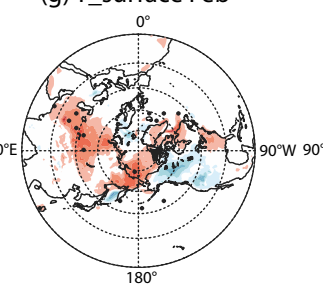

(l) (b) $-(\mathrm{g})$

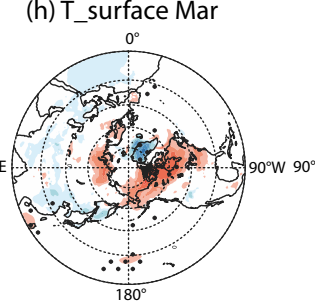

(m) $(\mathrm{c})-(\mathrm{h})$
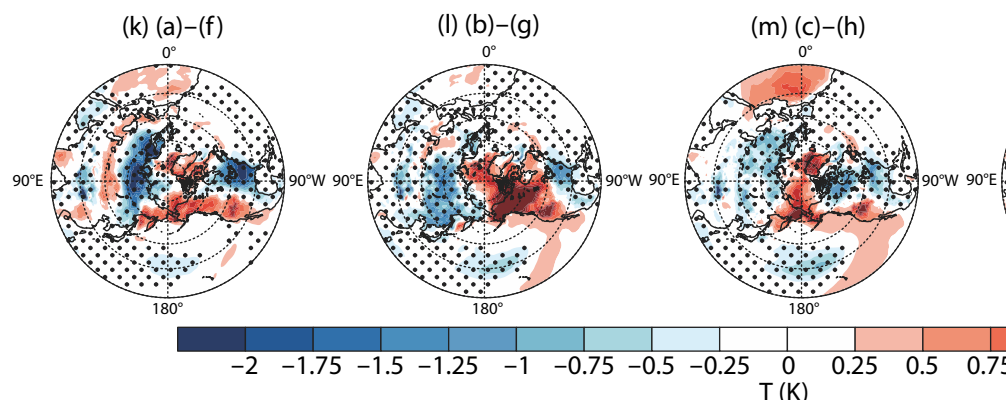

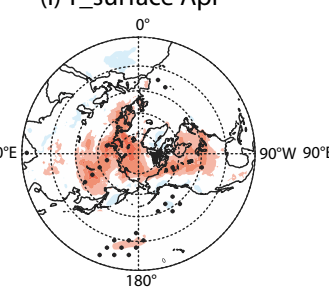

(n) (d)-(i)

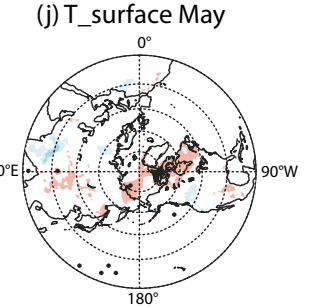

(o) (e)-(j)

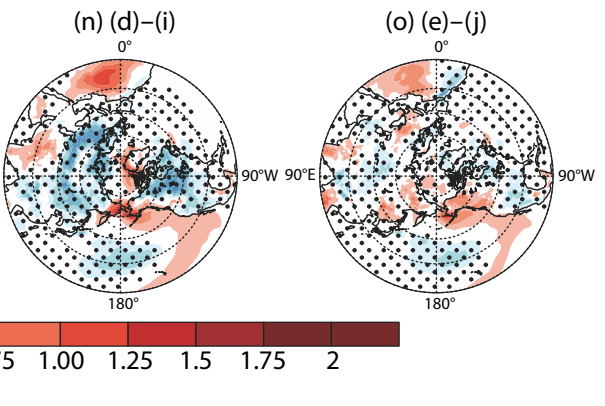

Figure 9. Composite evolution of the surface temperature anomalies (shadings; units: $\mathrm{K}$ ) in Northern Hemisphere extratropics from January to May for (top) strong stratospheric polar vortex events coupled to Arctic ozone loss in March (i.e., Arctic ozone loss events) and (middle) strong stratospheric polar vortex events uncoupled to Arctic ozone loss in March. (Bottom) the differences in surface temperature anomalies between the two cases. The dotted regions mark the composite anomalies or differences at the $95 \%$ confidence level. 
in the near surface persists even into May following significant Arctic ozone loss.

Comparing Arctic ozone loss and strong polar vortex events uncoupled with ozone loss, the evolution of the stratospheric NAM is distinct. The positive NAM associated with the Arctic ozone loss begins early in January, whereas the positive NAM begins in February for strong polar vortex events in early spring. As a result, the stratospheric NAM reverses earlier for Arctic ozone loss, and the positive NAM still does not decay in April when strong polar vortex events are uncoupled with ozone loss. The tropospheric responses to Arctic ozone loss and to the strong polar vortex uncoupled to ozone loss in early spring are distinct. Without Arctic ozone loss, the cold temperature anomalies associated with strong polar vortex events can extend from the stratosphere to the middle troposphere. Ozone loss in spring favors a warming of the near surface over the Arctic in late winter and early spring, which is due to less absorption of solar radiation in the stratosphere and arrival of more solar radiation at the surface. In contrast, the warm anomalies are biased toward the continents during strong polar vortex events without ozone loss.

Although the impact of the ozone depletion in the Antarctic on the troposphere has been recognized (Thompson et al., 2000; Thompson and Solomon, 2002; Shindell and Schmidt, 2004; Perlwitz et al., 2008; Son et al., 2009), the possible impact of the Arctic ozone loss on the troposphere is still controversial (Rex et al., 2004, 2006; Calvo et al., 2015; Ivy et al., 2017; Harari et al., 2019; Rao J and Garfinkel, 2020), which might be due to the previously limited sample size of Arctic ozone loss events and the large variability of the ozone and stratospheric circulation in the Northern Hemisphere. By using more samples from the historical runs by CESM2-WACCM, we have been able to determine that the pure impact of the ozone loss on the troposphere is significant, once the influence of the strong polar vortex is removed. The ozone impact on tropospheric temperature is consistent with the ozone anomaly distribution, implying that the thermodynamic process might be responsible for differences between the tropospheric response to Arctic ozone loss and to the strong polar vortex without ozone loss. Further investigation of the radiative process associated with the Arctic ozone loss and its separation from the dynamical AO response are not incorporated in this modelling study, thus left for future work.

\section{Acknowledgments}

The authors thank ECMWF (https://cds.climate.copernicus.eu) for providing the ERA5 reanalysis data. We acknowledge the High Performance Computing Center of Nanjing University of Information Science \& Technology for their support of this work. We thank the ESGF (https://esgf-node.IInl.gov/projects/esgf-IInl/) and NCAR for freely providing the CMIP6 simulations by CESM2-WACCM. All CMIP6 data used in this study are publicly available from ESGF. This study was supported by the National Natural Science Foundation of China (Grant NO. 91837311).

\section{References}

Arnone, E., Castelli, E., Papandrea, E., Carlotti, M., and Dinelli, B. M. (2012). Extreme ozone depletion in the 2010-2011 Arctic winter stratosphere as observed by MIPAS/ENVISAT using a 2-D tomographic approach. Atmos. Chem. Phys., 12(19), 9149-9165. https://doi.org/10.5194/acp-12-9149-2012

Ashmore, M. R. (2005). Assessing the future global impacts of ozone on vegetation. Plant Cell Environ., 28(8), 949-964. https://doi.org/10.1111/j.1365-3040.2005.01341.x

Bai, X. Y., Huang, K. M., Zhang, S. D., Huang, C. M. and Gong, Y. (2021). Anomalous changes of temperature and ozone QBOs in 2015-2017 from radiosonde observation and MERRA-2 reanalysis. Earth Planet. Phys., 5(3), 280-289. https://doi.org/10.26464/epp2021028

Bernhard, G., Dahlback, A., Fioletov, V., Heikkilä, A., Johnsen, B., Koskela, T., Lakkala, K., and Svendby, T. (2013). High levels of ultraviolet radiation observed by ground-based instruments below the 2011 Arctic ozone hole. Atmos. Chem. Phys., 13(21), 10573-10590. https://doi.org/10.5194/acp-1310573-2013

Butchart, N. (2014). The Brewer-Dobson circulation. Rev. Geophys., 52(2), 157-184. https://doi.org/10.1002/2013rg000448

Calvo, N., Polvani, L. M., and Solomon, S. (2015). On the surface impact of Arctic stratospheric ozone extremes. Environ. Res. Lett., 10(9), 094003. https://doi.org/10.1088/1748-9326/10/9/094003

Cao, C., Chen, Y. H., Rao, J., Liu, S. M., Li, S. Y., Ma, M. H., and Wang, Y. B. (2019). Statistical characteristics of major sudden stratospheric warming events in cesm 1-waccm: a comparison with the JRA55 and NCEP/NCAR reanalyses. Atmosphere, 10(9), 519. https://doi.org/10.3390/atmos10090519

Cheung, J. C. H., Haigh, J. D., and Jackson, D. R. (2014). Impact of EOS MLS ozone data on medium-extended range ensemble weather forecasts. J. Geophys. Res.: Atmos., 119(15), 9253-9266. https://doi.org/10.1002/2014jd021823

Chipperfield, M. P., Dhomse, S. S., Feng, W., McKenzie, R. L., Velders, G. J. M., and Pyle, J. A. (2015). Quantifying the ozone and ultraviolet benefits already achieved by the Montreal Protocol. Nat. Commun., 6, 7233. https://doi.org/10.1038/ncomms8233

Dennison, F. W., McDonald, A. J., and Morgenstern, O. (2015). The effect of ozone depletion on the Southern Annular Mode and stratospheretroposphere coupling. J. Geophys. Res.: Atmos., 120(13), 6305-6312. https://doi.org/10.1002/2014jd023009

Douglass, A. R., Newman, P., and Solomon, S. (2014). The Antarctic ozone hole: an update. Phys. Today, 67(7), 42-48. https://doi.org/10.1063/Pt.3.2449

Edmon, H. J. Jr., Hoskins, B. J., and Mcintyre, M. E. (1980). Eliassen-Palm cross sections for the troposphere. J. Atmos. Sci., 37(12), 2600-2616. https://doi.org/10.1175/1520-0469(1980)037<2600:EPCSFT>2.0.CO;2

Eyring, V., Waugh, D. W., Bodeker, G. E., Cordero, E., Akiyoshi, H., Austin, J., Beagley, S. R., Boville, B. A., Braesicke, P., ... Yoshiki, M. (2007). Multimodel projections of stratospheric ozone in the 21st century. J. Geophys. Res.: Atmos., 112(D16), D16303. https://doi.org/10.1029/2006jd008332

Eyring, V., Cionni, I., Bodeker, G. E., Charlton-Perez, A. J., Kinnison, D. E., Scinocca, J. F., Waugh, D. W., Akiyoshi, H., Bekki, S., ... Yamashita, Y. (2010). Multi-model assessment of stratospheric ozone return dates and ozone recovery in CCMVal-2 models. Atmos. Chem. Phys., 10(19), 9451-9472. https://doi.org/10.5194/acp-10-9451-2010

Eyring, V., Bony, S., Meehl, G. A., Senior, C. A., Stevens, B., Stouffer, R. J., and Taylor, K. E. (2016). Overview of the coupled model intercomparison project phase 6 (CMIP6) experimental design and organization. Geosci. Model. Dev., 9(5), 1937-1958. https://doi.org/10.5194/gmd-9-1937-2016

Farman, J. C., Gardiner, B. G., and Shanklin, J. D. (1985). Large losses of total ozone in Antarctica reveal seasonal $\mathrm{ClO}_{x} / \mathrm{NO}_{x}$ interaction. Nature, 315(6016), 207-210. https://doi.org/10.1038/315207a0

Fowler, D., Pilegaard, K., Sutton, M. A., Ambus, P., Raivonen, M., Duyzer, J., Simpson, D., Fagerli, H., Fuzzi, S., ... Erisman, J. W. (2009). Atmospheric composition change: ecosystems-Atmosphere interactions. Atmos. Environ., 43(33), 5193-5267. https://doi.org/10.1016/j.atmosenv. 2009.07.068

Harari, O., Garfinkel, C. I., Ziv, S. Z., Morgenstern, O., Zeng, G., Tilmes, S., Kinnison, D., Deushi, M., Jöckel, P., ... Davis, S. (2019). Influence of Arctic stratospheric ozone on surface climate in CCMI models. Atmos. Chem. Phys., 19(14), 9253-9268. https://doi.org/10.5194/acp-19-9253-2019

Hendon, H. H., Thompson, D. W. J., and Wheeler, M. C. (2007). Australian rainfall 
and surface temperature variations associated with the southern hemisphere annular mode. J. Climate, 20(11), 2452-2467.

https://doi.org/10.1175/JCLI4134.1

Hersbach, H., Bell, B., Berrisford, P., Hirahara, S., Horányi, A., Muñoz-Sabater, J., Nicolas, J., Peubey, C., Radu, R., ... Thépaut, J. N. (2020). The ERA5 global reanalysis. Quart. J. Roy. Meteor. Soc., 146(730), 1999-2049. https://doi.org/10.1002/qj.3803

Hu, Y. Y., and Xia, Y. (2013). Extremely cold and persistent stratospheric Arctic vortex in the winter of 2010-2011. Chin. Sci. Bull., 58(25), 3155-3160. https://doi.org/10.1007/s11434-013-5945-5

Huang, J. L., Tian, W. S., Zhang, J. K., Huang, Q., Tian, H. Y., and Luo, J. L. (2017). The connection between extreme stratospheric polar vortex events and tropospheric blockings. Quart. J. Roy. Meteor. Soc., 143(703), 1148-1164. https://doi.org/10.1002/qj.3001

Ivy, D. J., Solomon, S., Calvo, N., and Thompson, D. W. J. (2017). Observed connections of Arctic stratospheric ozone extremes to Northern Hemisphere surface climate. Environ. Res. Lett., 12(2), 024004. https://doi.org/10.1088/1748-9326/aa57a4

Karpechko, A. Y., Perlwitz, J., and Manzini, E. (2014). A model study of tropospheric impacts of the Arctic ozone depletion 2011. J. Geophys. Res.: Atmos., 119(13), 7999-8014. https://doi.org/10.1002/2013JD021350

Liu, S. M., Chen, Y. H., Rao, J., Cao, C., Li, S. Y., Ma, M. H., and Wang, Y. B. (2019). Parallel comparison of major sudden stratospheric warming events in CESM1-WACCM and CESM2-WACCM. Atmosphere, 10(11), 679. https://doi.org/10.3390/atmos10110679

Manney, G. L., Livesey, N. J., Santee, M. L., Froidevaux, L., Lambert, A., Lawrence, Z., Millan, L., Neu, J. L., Read, W. G., ... Fuller, R. (2020). Record-low Arctic stratospheric ozone in 2020: MLS observations of chemical processes and comparisons with previous extreme winters. Geophys. Res. Lett., 47(16), e2020GL089063. https://doi.org/10.1029/2020GL089063

Marshall, G. J., Orr, A., van Lipzig, N. P. M., and King, J. C. (2006). The impact of a changing Southern Hemisphere annular mode on Antarctic peninsula summer temperatures. J. Climate, 19(20), 5388-5404. https://doi.org/10.1175/JCLI3844.1

Newman, P. A., Gleason, J. F., McPeters, R. D., and Stolarski, R. S. (1997). Anomalously low ozone over the Arctic. Geophys. Res. Lett., 24(22), 2689-2692. https://doi.org/10.1029/97gl52831

Perlwitz, J., Pawson, S., Fogt, R. L., Nielsen, J. E., and Neff, W. D. (2008). Impact of stratospheric ozone hole recovery on Antarctic climate. Geophys. Res. Lett., 35(8), L08714. https://doi.org/10.1029/2008gl033317

Previdi, M., and Polvani, L. M. (2014). Climate system response to stratospheric ozone depletion and recovery. Quart. J. Roy. Meteor. Soc., 140(685), 2401-2419. https://doi.org/10.1002/qj.2330

Randel, W. J., and Wu, F. (1999). Cooling of the Arctic and Antarctic polar stratospheres due to ozone depletion. J. Climate, 12(5), 1467-1479. https://doi.org/10.1175/1520-0442(1999)012<1467:COTAAA>2.0.CO;2

Rao, J., and Ren, R. C. (2016). Asymmetry and nonlinearity of the influence of ENSO on the northern winter stratosphere: 2. Model study with WACCM. J. Geophys. Res.: Atmos., 121(15), 9017-9032. https://doi.org/10.1002/2015jd024521

Rao, J., Yu, Y. Y., Guo, D., Shi, C. H., Chen, D., and Hu, D. Z. (2019). Evaluating the Brewer-Dobson circulation and its responses to ENSO, QBO, and the solar cycle in different reanalyses. Earth Planet. Phys., 3(2), 166-181. https://doi.org/10.26464/epp2019012

Rao, J., and Garfinkel, C. I. (2020). Arctic ozone loss in March 2020 and its seasonal prediction in CFSv2: a comparative study with the 1997 and 2011 cases. J. Geophys. Res.: Atmos., 125(21), e2020JD033524. https://doi.org/10.1029/2020jd033524

Rao, J., and Garfinkel, C. I. (2021). The strong stratospheric polar vortex in March 2020 in sub-seasonal to seasonal models: implications for empirical prediction of the low arctic total ozone extreme. J. Geophys. Res.: Atmos., 126(9), e2020JD034190. https://doi.org/10.1029/2020jd034190

Renwick, J. A. (2002). Southern Hemisphere circulation and relations with sea ice and sea surface temperature. J. Climate, 15(21), 3058-3068. https://doi.org/10.1175/1520-0442(2002)015<3058:SHCARW>2.0.CO;2

Rex, M., Salawitch, R. J., von der Gathen, P., Harris, N. R. P., Chipperfield, M. P., and Naujokat, B. (2004). Arctic ozone loss and climate change. Geophys. Res. Lett., 31(4), L04116. https://doi.org/10.1029/2003GL018844

Rex, M., Salawitch, R. J., Deckelmann, H., von der Gathen, P., Harris, N. R. P., Chipperfield, M. P., Naujokat, B., Reimer, E., Allaart, M., ... Zerefos, C. (2006). Arctic winter 2005: implications for stratospheric ozone loss and climate change. Geophys. Res. Lett., 33(23), L23808. https://doi.org/10.1029/2006gl026731

Roscoe, H. K. (2006). The Brewer-Dobson circulation in the stratosphere and mesosphere - Is there a trend. Adv. Space Res., 38(11), 2446-2451. https://doi.org/10.1016/j.asr.2006.02.078

Rowland, F. S. (2006). Stratospheric ozone depletion. Philos. Trans. R. Soc. B: Biol. Sci., 361(1469), 769-790. https://doi.org/10.1098/rstb.2005.1783

Shi, C. H., Cai, J., Guo, D., Xu, T., and Lu, Y. (2018). Responses of stratospheric temperature and Brewer-Dobson circulation to 11-year solar cycle in boreal winter. Trans. Atmos. Sci. (in Chinese), 41(2), 275-281. https://doi.org/10.13878/j.cnki.dqkxxb.20160101001

Shindell, D. T., and Schmidt, G. A. (2004). Southern Hemisphere climate response to ozone changes and greenhouse gas increases. Geophys. Res. Lett., 31(18), L18209. https://doi.org/10.1029/2004gl020724

Smith, K. L., and Polvani, L. M. (2014). The surface impacts of Arctic stratospheric ozone anomalies. Environ. Res. Lett., 9(7), 074015. https://doi.org/10.1088/ 1748-9326/9/7/074015

Smith, K. L., and Polvani, L. M. (2017). Spatial patterns of recent Antarctic surface temperature trends and the importance of natural variability: lessons from multiple reconstructions and the CMIP5 models. Climate Dyn., 48(7-8), 2653-2670. https://doi.org/10.1007/s00382-016-3230-4

Smyshlyaev, S. P., Vargin, P. N., Lukyanov, A. N., Tsvetkova, N. D., and Motsakov, M. A. (2021). Dynamical and chemical processes contributing to ozone loss in exceptional Arctic stratosphere winter-spring of 2020. Atmos. Chem. Phys. Discuss, 2021, 1-35. https://doi.org/10.5194/acp-2021-11

Solomon, S., Garcia, R. R., Rowland, F. S., and Wuebbles, D. J. (1986). On the depletion of Antarctic ozone. Nature, 321(6072), 755-758. https://doi.org/10.1038/321755a0

Solomon, S. (1999). Stratospheric ozone depletion: a review of concepts and history. Rev. Geophy., 37(3), 275-316. https://doi.org/10.1029/1999rg900008

Solomon, S., Haskins, J., Ivy, D. J., and Min, F. (2014). Fundamental differences between Arctic and Antarctic ozone depletion. Proc. Natl. Acad. Sci. USA, 111(17), 6220-6225. https://doi.org/10.1073/pnas.1319307111

Son, S. W., Tandon, N. F., Polvani, L. M., and Waugh, D. W. (2009). Ozone hole and Southern Hemisphere climate change. Geophys. Res. Lett., 36(15), L15705. https://doi.org/10.1029/2009gl038671

Stolarski, R. S., Krueger, A. J., Schoeberl, M. R., McPeters, R. D., Newman, P. A., and Alpert, J. C. (1986). Nimbus 7 satellite measurements of the springtime Antarctic ozone decrease. Nature, 322(6082), 808-811. https://doi.org/10.1038/322808a0

Stone, K. A., Solomon, S., Kinnison, D. E., Baggett, C. F., and Barnes, E. A. (2019). Prediction of Northern Hemisphere regional surface temperatures using stratospheric ozone information. J. Geophys. Res.: Atmos., 124(12), 5922-5933. https://doi.org/10.1029/2018jd029626

Tang, Z., Guo, D., Su, Y. C., Shi, C. H., Zhang, C. X., Liu, Y., Zheng, X. D., Xu, W. W., Xu, J. J., Liu, R. Q., and Li, W. L. (2019). Double cores of the Ozone Low in the vertical direction over the Asian continent in satellite data sets. Earth Planet. Phys., 3(2), 93-101. https://doi.org/10.26464/epp2019011

Thiéblemont, R., Matthes, K., Orsolini, Y. J., Hauchecorne, A., and Huret, N. (2016). Poleward transport variability in the Northern Hemisphere during final stratospheric warmings simulated by CESM(WACCM). J. Geophys. Res.: Atmos., 121(18), 10394-10410. https://doi.org/10.1002/2016jd025358

Thompson, D. W. J., Wallace, J. M., and Hegerl, G. C. (2000). Annular modes in the extratropical circulation. Part II: trends. J. Climate, 13(5), 1018-1036. https://doi.org/10.1175/1520-0442(2000)013<1018:AMITEC>2.0.CO;2

Thompson, D. W. J., and Solomon, S. (2002). Interpretation of recent Southern Hemisphere climate change. Science, 296(5569), 895-899. https://doi.org/10.1126/science.1069270

Thompson, D. W. J., Solomon, S., Kushner, P. J., England, M. H., Grise, K. M., and Karoly, D. J. (2011). Signatures of the Antarctic ozone hole in Southern Hemisphere surface climate change. Nat. Geosci., 4(11), 741-749. 
https://doi.org/10.1038/Ngeo1296

Tilmes, S., Richter, J. H., Kravitz, B., MacMartin, D. G., Mills, M. J., Simpson, I. R., Glanville, A. S., Fasullo, J. T., Phillips, A. S., ... Ghosh, S. (2018). CESM1 (WACCM) stratospheric aerosol geoengineering large ensemble project. Bull. Am. Meteor. Soc., 99(11), 2361-2371. https://doi.org/10.1175/ bams-d-17-0267.1

Turnock, S. T., Wild, O., Sellar, A., and O'Connor, F. M. (2019). 300 years of tropospheric ozone changes using CMIP6 scenarios with a parameterised approach. Atmos. Environ., 213, 686-698. https://doi.org/10.1016/ j.atmosenv.2019.07.001

World Meteorological Organization. (2002). Scientific assessment of ozone depletion: 2014. Geneva: World Meteorological Organization.

Xia, Y., Huang, Y., and Hu, Y. Y. (2018). On the climate impacts of upper tropospheric and lower stratospheric ozone. J. Geophys. Res.: Atmos., 123(2), 730-739. https://doi.org/10.1002/2017jd027398

Xie, F., Tian, W. S., and Chipperfield, M. P. (2008). Radiative effect of ozone change on stratosphere-troposphere exchange. J. Geophys. Res.: Atmos.,
113(D7), D00B09. https://doi.org/10.1029/2008jd009829

Zhang, Y., Wang, W. H., Li, X. J., Zhang, X. Y., Zheng, Z. J., and Liu, R. X. (2013). Anomalously low ozone of 1997 and 2011 Arctic spring: monitoring results and analysis. Adv. Polar Sci., 23(2), 82-86.

https://doi.org/10.3724/sp.J.1085.2012.00082

Zhang, Y. L., Cai, Z. N., and Liu, Y. (2021). The exceptionally strong and persistent Arctic stratospheric polar vortex in the winter of 2019-2020. Atmos. Ocean Sci. Lett., 14(2), 100035.

https://doi.org/10.1016/j.aosl.2021.100035

Zhang, Z. M., Rao, J., Guo, D., Zhang, W. H., Li, L. P., Tang, Z., Shi, C. H., Su, Y. C., and Zhang, F. Y. (2019). Interdecadal variations of the midlatitude ozone valleys in summer. Atmosphere, 10(11), 677. https://doi.org/10.3390/atmos10110677

Zubiaurre, l., and Calvo, N. (2012). The El Niño-Southern Oscillation (ENSO) Modoki signal in the stratosphere. J. Geophys. Res.: Atmos., 117(D4), D04104. https://doi.org/10.1029/2011jd016690 